\title{
What Causes Patient Aggressive Behaviours in Healthcare Settings?
}

\author{
Tawanda Machingura ${ }^{1 *}$ and Chris Lloyd ${ }^{2}$ \\ ${ }^{1}$ Assistant Professor of Occupational Therapy, Bond University, Gold Coast, Australia \\ ${ }^{2}$ Senior Research Fellow, Griffith University, Gold Coast, Australia
}

Submission: February 7, 2019; Published: February 25, 2019

*Corresponding author: Tawanda Machingura, Assistant Professor of Occupational Therapy, Faculty of Health Sciences and Medicine, Bond University, Gold Coast, Australia

\section{View point}

Health staff such as nurses and doctors are often victims of aggressive behaviour displayed by patients in hospital and health care settings particularly dementia units, emergency departments and mental health units. In Australia, there is currently an increased media attention on the topic however employers are still unsure of the causes or how to manage their ever-increasing scourge. The commonly pointed out scape goat has been the use of alcohol and drugs. Although this is a likely culprit it is not the only cause of such behaviours. This paper therefore seeks to examine the causes of patient aggressive behaviours and provide a more critical view to the problem and therefore enable solution focused thinking that actually will work. Research indicates that staff exposure to patient violence leads to poor outcomes for the patients, staff and employers [1]. Staff are more likely to have a lower job satisfaction, emotional exhaustion, cynicism, physical injury and poor psychological wellbeing and employers incur higher costs due to injury claims.
Therefore, preventing aggressive behaviours has benefits for staff, patients and employers.

Understanding what causes aggressive behaviours is important for effectively reducing aggressive behaviour incidents in hospital settings. We know from previous studies that aggressive behaviours range from verbal abuse and physical violence to damage to property [2], International Council of Nurses (2009). Current literature generally categorizes risk factors into patient factors, environmental factors, treatment factors and societal factors [1]. We agree with this view but emphasize that these factors are not static but rather interactional. Our view is that in line with systems theory, one factor is hardly the only cause of aggressive behaviour. We argue that aggressive behaviour is the result of an interaction between negative patient, staff, environment and contextual factors as shown in Figure 1 below.

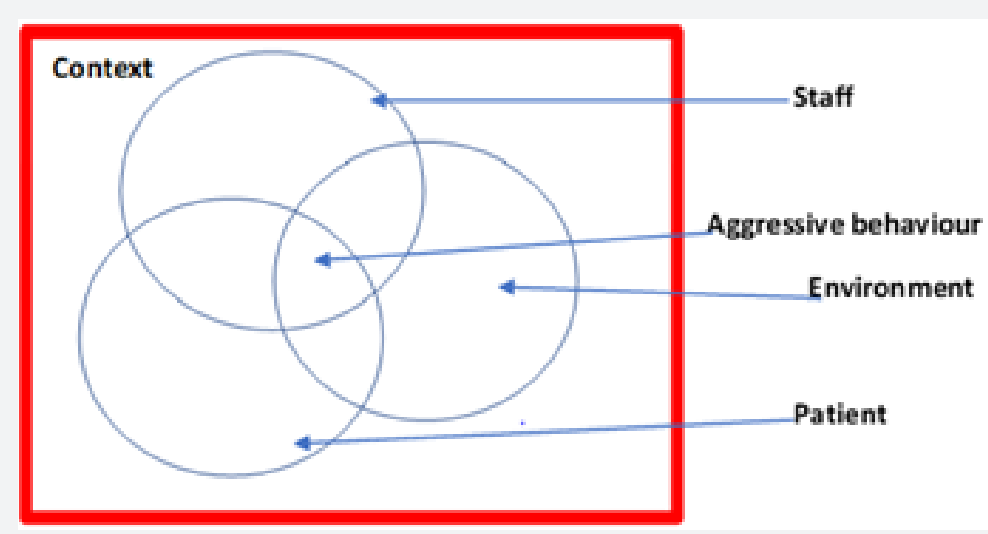

Figure1: Likelihood of aggressive behaviour conceptualisation.

These factors are heterarchical in that no one factor is more important than another and all elements are unranked. Any one of the factors can become the key cause of the aggressive behaviour depending on the circumstances. This conceptualisation assumes that the more there is a negative interaction between the staff, patient and environment factors within a given context 
the more likely is aggressive behaviour to occur. The implication for management is therefore to take a more holistic systems approach to reduce this interaction focusing on patients, staff, environment and context rather than just one thing such as intoxication. Such a model allows policy makers to come up with robust and effective organisational policies to assess and manage the risk of aggression towards staff or property. The specific factors of the patient, staff, environment and context are outlined in Figure 2 below.

\begin{tabular}{|c|c|c|c|}
\hline Patient Factors & Staff Factors & $\begin{array}{c}\text { Environmental } \\
\text { Factors }\end{array}$ & Context \\
\hline $\begin{array}{l}\text { - Symptoms of an illness } \\
\text { eg, mood, delusions, } \\
\text { hallucinations, thought } \\
\text { disorder, lack of } \\
\text { insight, poor } \\
\text { judgement } \\
\text { - Personality style eg } \\
\text { impulsive narcissistic, } \\
\text { eccentric, dependent, } \\
\text { antisocial } \\
\text { Intoxication from } \\
\text { drugs or alcohol } \\
\text { Adverse reaction to } \\
\text { prescribed } \\
\text { medications } \\
\text { Cognitive impairment } \\
\text { eg dementia, } \\
\text { intellectual disability, } \\
\text { delirium } \\
\text { Inadequate coping } \\
\text { strategies } \\
\text { - Gender, age and } \\
\text { culture mismatched to } \\
\text { care providers } \\
\text { Transference } \\
\text { - Patient and service } \\
\text { goals mismatch } \\
\text { Somatization } \\
\text { - Factitious, malingering } \\
\text { or exaggeration } \\
\text { Non-adherence to } \\
\text { prescribed treatment }\end{array}$ & $\begin{array}{l}\text { - High } \\
\text { workloads } \\
\text { - Low job } \\
\text { satisfaction } \\
\text { Lack of de- } \\
\text { escalation } \\
\text { skills } \\
\text { - Lack of post } \\
\text { graduate } \\
\text { qualification } \\
\text { Poor } \\
\text { communicatio } \\
\text { n skills } \\
\text { - Inexperience } \\
\text { - Burnout, } \\
\text { depression } \\
\text { and anxiety } \\
\text { Counter } \\
\text { transference } \\
\text { Negative } \\
\text { reactions to } \\
\text { certain } \\
\text { patients } \\
\text { Controlling } \\
\text { behaviours } \\
\text { - Lack of empath } \\
\text { Projection of } \\
\text { intolerable } \\
\text { feelings to } \\
\text { patients } \\
\text { Hopefulness of } \\
\text { clinician }\end{array}$ & $\begin{array}{l}\text { Physical space, } \\
\text { furniture, fittings, } \\
\text { colours, noise, } \\
\text { excessive sensory } \\
\text { stimulation } \\
\text { - Social- } \\
\text { relationship with } \\
\text { staff, family and } \\
\text { other patients } \\
\text { - Institutional- } \\
\text { rules, policies and } \\
\text { procedures that } \\
\text { are restrictive } \\
\text { Cultural- } \\
\text { paternalism vs } \\
\text { autonomy, } \\
\text { recovery } \\
\text { orientated }\end{array}$ & 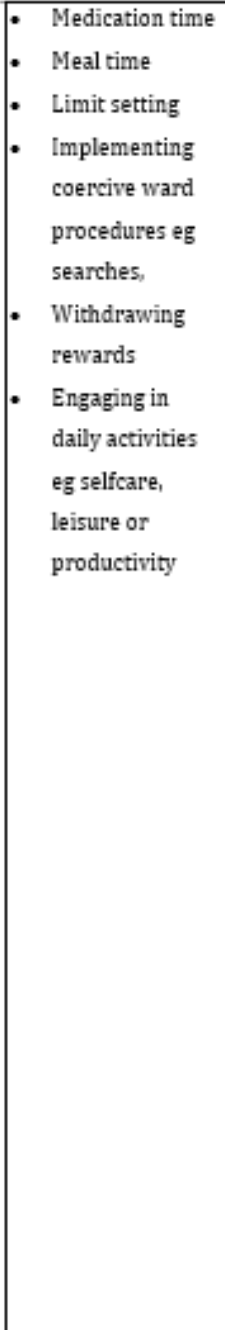 \\
\hline
\end{tabular}

Figure 2: Outline of patient, staff, environment and contextual factors that impact on aggressive behaviours.

We argue that trying to manage each factor individually is unhelpful and the use of systems theory thinking is much more likely to yield positive results. We suggest a more holistic view to aggressive behaviour causes in healthcare settings as a way of enabling services to make sound policies on aggressive behaviours in health care going forward and avoid knee jerk reactions that might even make the situation worse for staff, patients and employers.

\section{References}

1. Waschgler K, Ruiz-Hernández J, Llor Esteban B, García-Izquierdo M (2013) Patients' aggressive behaviours towards nurses: Development and psychometric properties of the hospital aggressive behaviour scale- users. J Adv Nurs 69(6): 1418-1427.

2. Estryn-Behar M, Van der Heijden B, Camerino D, Fry C, Le Nezet O, et al. (2008) Violence risk in nursing - results from the European NEXT Study. Occup Med (Lond) 58: 107-114. 
This work is licensed under Creative Commons Attribution 4.0 License

DOI: 10.19080/PBSIJ.2019.10.555796

\section{Your next submission with Juniper Publishers will reach you the below assets}

- Quality Editorial service

- Swift Peer Review

- Reprints availability

- E-prints Service

- Manuscript Podcast for convenient understanding

- Global attainment for your research

- Manuscript accessibility in different formats ( Pdf, E-pub, Full Text, Audio)

- Unceasing customer service

Track the below URL for one-step submission https://juniperpublishers.com/online-submission.php 